\title{
KEKERASAN DAN PROBLEM DIALOG ANTAR AGAMA DI INDONESIA
}

Oleh: Zuly Qodir

Abstract

This articles attempts to describe religion violence. Why religions are raised violence roots? What is problem of the religion dialogue in Indonesia? How is prospect religious dialogue? How to construct a mutual dialogue? This article declares that violence of religions because of sacred text, dogma and the interpretation of text. Absolutely versus relatively, and humanism versus God. Violence of religions departs from ulama, pastor, religious leader, missionaries and religious teacher. Religions ambivalence between peace and violence, because in the religion on text and context are very rigid. The holy war was justified by religious text. Among problems of religious dialogue are collective identity, minority and majority issues, Christianization and Islamization issues, and the conversion of religion. Continued dialogue with cutting crucial issues; collective identity, minority-majority, Christianization andIslamization and conversion.

نحلاصة

إن مذا البحث تد قام ممناقشة مسالة تأحذ أهمية كبيزة على الساحة السياسية في الوتت اللماضر، ألا ومي العنف الذي يأحذ من الدين كمصدر له، إن الاختبار الذي قد قامه

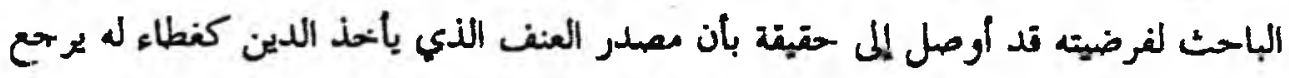
إلى الآياته رالأقوال والتفسرات التي تد حيكت نطريقه حدية لا تنطيت بع أسباب الترول قي أغلب الأحيان وتأخذ من الاطلاق الغير لازم كأساس لما. فتضعنا أمام حقيقة بضمنها

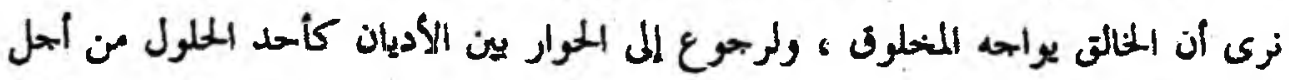

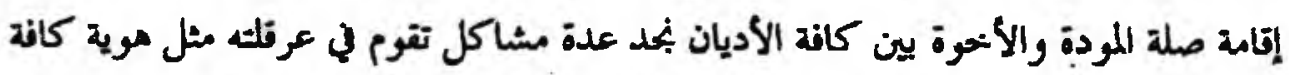

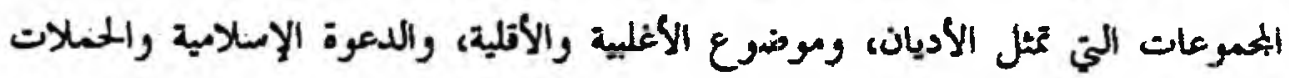

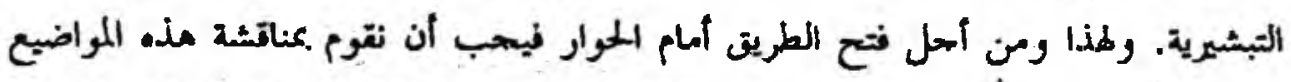

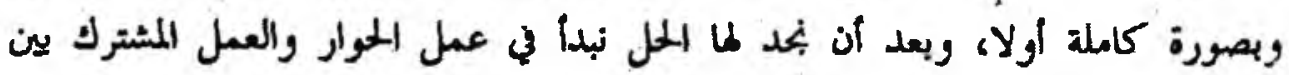

Kata Kunci: Kekerasan, Teks, Dialog antar Agama

\footnotetext{
'Mahasiswa S3 Sosiologi Universitas Gadjah Mada Yogyakarta, staf Lembaga Kajian Islam dan Sosial (LKiS) Yogyakarta, dan alumni Program Magister Studi Islam UII.
} 


\section{A Pendahuluan}

Tekerasan simbolik dan manifesnya telah banyak dibicarakan, ditulis, dan 焦 dianalisis orang dalam pelbagai forum, baik seminar, diskusi maupun iwkakarya. Namun, semakin dibahas, seakan-akan kekerasan malah nenimbulkan mati rasa, bahkan kekerasan bertambah banyak dengan eskalasinya yang meningkat terus-menerus. Semakin kita sering membahas kekerasan, seakan-akan juga membenarkan pandangan bahwa bangsa ini memang secara historis dibangun dengan kekerasan dan pemberontakan. Kekerasan akhirnya menjadi semacam komoditi politik sekelompok orang tertentu yang mempunyai tujuan tertentu pula. Kekerasan politik muncul berbarengan dengan semakin semangatnya orang menuntut demokrasi, dan kerinduan akan perdamaian.

Sementara itu, jika kekerasan tidak dibicarakan, kita juga merasa bersalah, karena seakan-akan tidak peduli dengan kejadian yang menimpa rakyat banyak sebagai bagian dari masyarakat. Sense of crisis terhadap gejolak yang muncul di masyarakat benar-benar diuji. Dengan membicarakan dan membahas kekerasan sedikitnya diharapkan dapat ditemukan akar masalah atau persoalan yang menjadi triger-nya sehingga memungkinkan solusinya. Pendek kata, kekerasan ibarat pedang bermata dua yang sama-sama penting dan tajamnya. Salah satu dari keduanya senantiasa saling mempengaruhi, dan inherent.

Kekerasan seperti di atas, bukan saja bersifat personal-individual, tetapi merebak menjadi konflik bersifat kolektif. Konflik seperti ini dikenal dengan konflik sosial, sekalipun bermula dari konflik yang sifatnya personal. Beberapa kekerasan yang terjadi menunjukkan betapa kekerasan menunjukkan peningkatannya di tanah air kita ini, sejak dari Situbondo 1996, Tasikmalaya 1997, Jakarta, Solo 1998, Kupang 1999, Sanggauledo, 1997, Sambas 1999, Ambon 1999, Pontianak 2000, Mataram 2000, dan Jakarta 2001.

Di tengah makin banyaknya konflik sosial yang terjadi, terdapat masalah yang paling sensitif menjadi bagian dari konflik sosial tersebut. Masalah yang sensitif itu adalah agama. Agama menjadi bagian yang sarat dengan konflik dan kekerasan. Paling tidak agama menjadi perekat untuk munculnya sentimen dan solidaritas kelompok untuk melawan kelompok yang lainnya. Kita sebagai orang beragama memang kadang sulit mempercayainya, mengapa orang beragama demikian brutal sikapnya, tega menghabisi nyawa sesama dan tega melakukan perampokan, dan pembakaran rumah-rumah dimana nama Tuhan diperdengarkan. Benarkah Tuhan punya masa depan, dan benarkah Tuhan masih hidup bersama kaum agamawan? Menjadi pertanyaan yang penting dikemukakan untuk menggugah keberagamaan kita secara kritis.

Dalam tulisan ini, penulis mengawali dengan deskripsi singkat tentang rezim Orde Baru dengan segala sepak terjangnya selama 32 tahun. Di Indonesia, secara agak khusus tulisan ini juga akan membahas ambivalensi yang timbul dari agama, sehingga menimbulkan kedamaian, kesejahteraan tetapi sekaligus 
menumbuhkan kebencian, kekerasan dan peperangan. Kemudian akan diakhiri dengan mengemukakan beberapa agenda yang penting dalam membangun dialog hubungan antar agama, dimana hal ini telah sekian lama "terpenjara" sehingga kemudian akan muncul semacam jalan keluar demi hubungan antar agama yang lebih riil, bukan basa-basi, seremonial, untuk mewujudkan masyarakat Indonesia yang beradab dan demokratis. Dan paling akhir dari tulisan ini ingin mengemukakan lembaga-lembaga yang mungkin bisa . mengambil peran dalam rangka membangun perdamaian berdasarkan agama.

\section{B. Pengalaman Rezim Orde Baru}

Sejak 1998, konflik kekerasan di negeri ini meningkat derajatnya. Orang seakan dipaksa hidup dalam darurat perang, sehingga harus senantiasa waspada jika ada serangan-serangan mendadak. Situasi darurat perang ini bisa kita perhatikan dengan munculnya banyak pasukan-pasukan militeris (militer/milisi), baik dari kalangan militer sendiri maupun sipil yang acapkali menggunakan simbol-simbol dan cara-cara kekerasan dalam menyelesaikan masalah, tidạk ada komprorni di sana, apalagi mengutamakan dialog. Dialog bahkan mengalami kemacetan total, karena yang terjadi adalah pemaksaanpemaksaan atas pandangan dan pendapatnya yang dianggap paling absolut, sehingga orang lain tidak perlu dihitung.

Ironis memang, sebuah negara yang dikatakan religious society, ternyata jalan-jalan non violence sebagaimana diisyaratkan dalam agama-agama tidak menjadi pijakan utama dalam mencari jalan keluar untuk menangani krisis nasional. Pilihan utama yang dilakukan bahkan kekerasan; baik kekerasan simbolik maupun manifes. Kekerasan simbolik digunakan dalam ungkapanungkapan atau percakapan pergaulan yang acapkali menyinggung perasaan dan diskriminatif, dimana prejudice dan stereotipe menjadi pilihan utama yang berlaku, misalnya terhadap etnis Cina, Jawa dan sebagainya. Sementara, kekerasan manifest terjadi dalam banyak kasus kerusuhan, dimana pemaksaan pendapat dengan pengerahan massa di jalan-jalan, perusakan fasilitas umum, penjarahan, penculikan dan pembunuhan baik dengan senjata tajam maupun dengan senjata api milik tentara (baca: pistol, granat dan bom) terjadi. .

Macetnya tradisi dialog berakibat pada munculnya tradisi kekerasan dan pemaksaan, sehingga harapan tumbuhnya demokrasi sipil (civil democratic) agak terhambat. Budaya civilities dalam masyarakat kita mengalami sebuah involusi. Harapan munculnya civil society akhirnya entah kapan bisa tercapai, karena riilnya yang berkembang adalah budaya violence. Pertanyaannya, apakah sebuah keniscayaan bagi sebuah bangsa yang hendak demokratis harus mengalami segala macam bencana atau tragedi kekacauan (horror dan chaos)? Penulis tidak tahu pasti jawabannya, namun jika boleh penulis menduga hal ini karena kita tengah mengalami transisi politik; yaitu sebuah keadaan pancaroba dari budaya politik otoriter, monolit, serakah, seragam dan fasis menuju pada 
budaya politik yang lebih terbuka, dan demokratis yang membawa kita pada civil society dan demokrasi.

Transisi politik yang sekarang bangsa Indonesia sedang alami merupakan akibat dari kurang lebih 32 tahun kita tidak pernah diajar dan dilatih untuk berbeda pendapat. Para elit politik selama kurun waktu tersebut lebih banyak tampil sebagai penguasa, dan aparatnya tak lebih dari sekedar babu, jongos dan bandit, karena itu baik penguasa (elit) maupun pembantunya merepresentasikan dirinya sebagai "budak", dan tidak memiliki sense of crisis apalagi sense of ethic. Para penguasa dan birokrasinya hanya diajar untuk menumpuk kekayaan dan kesenangan pribadi, keluarga dan kroninya. Oleh sebab itu, budaya KKN benarbenar telah mendarah daging. Bagaimana merubah budaya KKN inilah yang merupakan tugas berat yang harus segera dilakukan, jika bangsa ini tidak ingin mengalami chaos yang lebih besar dan kebangkrutan negara. Jika bangsa ini terus dilanda chaos dan kebangkrutan, maka tak khayal negara ini akan menjadi republik horor, sebuah republik yang senantiasa dihantui perasaan was-was dari ancaman teror (bom, penculikan, pembunuhan dan sebagainya). Barangkali tidak berlebihan jika dituduh rezim Orde Baru telah menjadikan kehidupan bangsa ini menjadi sebuah episode yang panjang tentang mimpi buruk yang penuh tragedi politik berdarah di negeri sendiri sepanjang abad ke- 20 .

Pengalaman pahit selama 32 tahun tentang birokrasi yang korup sudah cukup, untuk kemudian beranjak pada sebuah bangunan negara yang lebih beradab dan memiliki visi dan misi ke depan. Salah satu visi yang harus diemban adalah bagaimana secara perlahan-lahan, namun pasti aparat birokrasi negara harus memiliki political will untuk menciptakan clean government dan good governance.

Tidak dimilikinya visi dan misi clean government dan good governance jelas karena penguasa dan aparat birokrasinya tidak memiliki sense of crisis, akibatnya adalah upaya penyeragaman dalam seluruh wilayah kehidupan masyarakat. Berbeda pendapat dengan kebijakan rezim sama artinya dengan menggali lubang kuburnya sendiri, maka bersiaplah untuk dikuburkannya ke sana. Berbeda pendapat adalah subversif, karena itu layak "diamankan", sebuah eufemisme atas mereka yang akan dimasukkan penjara.

Hal semacam itu terjadi dalam kehidupan beragama dan bahkan agama itu sendiri. Orang beragama harus sesuai dengan agama resmi negara, tidak ada pilihan atau peluang untuk berbeda dengan agama di luar negara (baca: Islam, Kristen, Hindu, Budha dan Katolik). Ekspresi keimanan seseorang terkerangkeng oleh otoritas negara. Melakukan pilihan di luar agama resmi negara, bersiaplah untuk dituduh "sesat", karena itu siap-siap juga untuk dibasmi dengan kekerasan senjata. Kasus pembantaian para pengeikut Haur Koneng di Jabar beberapa tahun lalu adalah bukti tentang hal ini. Hal yang sama juga terjadi pada pengikut Teungku Bantaqiah. Belum lagi kasus pengamanan terhadap para pengikut Kaharingan di pedalaman Kalimantan, "pengimanan" 
pengikut Islam Wetu Telu di Lombok', penganut Saminisme di Blora, dan pengagamaan terhadap pengikut Konghucu merupakan bentuk-bentuk bagaimana negara bersikap sangat otoriter dan dominatif atas keberagamaan masyarakatnya.

Selain itu, terjadi ideologisasi agama sehingga agama tidak lebih dari sebuah ideologi politik kekuasaan. Agama dikonstruksikan scbagaimana negara menafsirkan, dan celakanya konstruksi negara tentang agama adalah konstruksi hitam-putih yang sangat politis, karena itu tidak ada ruang publik di sana. Akhirnya keberagamaan masyarakat adalah keberagamaan yang monolit dan tidak ada dialog di sana. Kalaupun ada dialog antar agama, yang terjadi sesungguhnya bukan dialog, tetapi "parade pidato" yang dilakukan oleh elit-elit agama dan elit politik yang harus didengarkan oleh umat atau jamaahnya. Umat tidak pernah dilibatkan dalam membahas masalah-masalah mereka sendiri. Politisi (elit politik) dan agama merasa paling paham atas masalah umatnya, sehingga tidak perlu melibatkan grass root. Inilah yang menjadi salah satu kesalahan dan kegagalan dialog antar agama yang dilakukan. Di samping tidak melibatkan umat atau jamaah, juga hanya berdasarkan proyek kekuasaan yang sangat seremonial. Oleh sebab itu jika kita hendak melakukan dialog antar agama, yang harus kita pertimbangkan adalah apa yang sebenarnya menjadi kebutuhan umat atau jamaah, bukan kebutuhan elite. Dialog juga harus dilakukan dengan jujur dan terbuka tanpa adanya agenda-agenda tersembunyi di bekalangnya. Apa yang pernah terjadi di era rezim Orde baru terhadap agama dan lembaga-lembaga agama harus dikubur habis, sehingga kesalahan dalam wilayah yang crusial tidak ternoda dan coreng-moreng dengan dosa-dosa.

\section{Ambivalensi Agama}

Sebagai sebuah entitas, agama kadang terkesan memiliki dua wajah yang sama-sama hadir. Pada satu sisi wajahnya menghadirkan kedamaian, keselamatan, dan keramahan, namun di sisi lain ia juga menghadirkan wajah yang ganas, galak, bahkan penuh peperangan sehingga sangat mengerikan bagi orang beragama itu sendiri. Sisi paling jelas dari wajah ngeri agama adalah munculnya ideologi "perang suci" yang dipunyai pada tiga agama Abraham (Ibrahim), sehingga berbuah pada adanya persengketaan tiada henti tentang tanah Palestina-Yerusalem (Israel-Palestina). Ide tentang perang suci ini, bahkan menyebabkan polarisasi klerikalisme, terorisme yang bukan saja bersifat etnis, tetapi sekaligus agama, seperti di India, antara Budha dan Hindu di Punjab. ${ }^{2}$

Pertanyaan yang patut dikemukakan kepada publik, bagaimana sebuah pertunjukan kekerasan itu berbentuk? Ternyata berdasarkan sebuah kajian yang

\footnotetext{
'Mengenai Islam Wetu Telu dapat dilihat dalam karya Emi Budiwanti, 2001, Islam Sasak, Yogyakarta: L.KiS.

"James Turner Johnson, "The Holy War Idea in Western and Islamic Tradition", dalam Ali Noor Zaman (terj.), 2002, Ide Perang Suci dalam Tradisi Islam dan Barat, Yogyakarta: Qalam, hal. 52.
} 
cukup mendalam menyatakan bahwa pertunjukkan kekerasan muncul dalam bentuk yang sangat sistematik. Kekerasan berlatar belakang agama dirancang dengan sebuah strategi yang handal sehingga menjadikannya sebuah pertunjukkan yang sangat dramatik. Kekerasan tersebut hampir bisa dipastikan senantiasa berhubungan dengan strategi politik, yang menjadi cover dari seluruh aksi terorisme politik. Apa yang terjadi di Israel dan Palestina merupakan bukti-bukti yang sulit dibantah tentang terjadinya terorisme berbaju agama tersebut. ${ }^{3}$

Apa yang terjadi dengan agama pada akhirnya saling berhadap-hadapan antara universalisme dengan partikularisme. Antara keinginan berdamai dengan keinginan berperang. Belakangan keinginan berperang tampaknya lebih dominan, disebabkan pemahaman doktrin jihad yang lebih mengarah pada perang fisik, angkat senjata dan permusuhan. Bukan jihad dalam arti bersungguh-sungguh melawan segala yang menjadi tirani, dan kemunafikan. Dengan tafsir jihad yang cenderung seperti itu, maka agama dengan kekerasan sangat sulit dipisahkan, bahkan menjadi selffullfiling prophecy.

Tentu sebagai orang beriman, hanya ingin menghadirkan wajah agama yang sangar, galak dan peperangan rasanya menjadi tidak bijaksana, Keagamaan kita barangkali masih perlu dipertanyakan, dan kemudian diperbaharui untuk menuju keberagamaan yang lebih santun, sopan dan beradab. Di sinilah sebetulnya keagamaan yang lebih mencerminkan kearifan, bukan kesombongan dan keangkuhan karena merasa "membela Tuhan" menjadi tidak terlału penting. Keagamaan menjadi sangat pribadi sifatnya. Publik tidak menjadi sorotan utama dalam keagamaan karena keagamaan sifat pertanggungjawabannya juga pribadi-pribadi. Kekerasan pun akhirnya bisa bersifat pribadi, sekaligus kelompok orang beragama.

Kekerasan yang berlindung di belakang baju agama inilah yang kita sebut sebagai sacred violence karena berada di belakang "baju agama", dimana seakan-akan mendapatkan justifikasi dari dalil-dalil, doktrin agama, teks suci, dan tafsir agama. Kekerasan jenis ini (sacred violence) menjadi kekerasan yang terhormat, karena menurut sejarah dan norma dianggap melindungi agama atau malahan membasmi orang-orang yang hendak merusak agama. Sacred violence ini pada akhirnya menjadi kekerasan yang diabadikan dengan norma-norma suci agama-agama.

Beberapa contoh kekerasan yang "berlindung di balik baju agama", bisa disebutkan, misalnya kekerasan yang terjadi di Kupang, Nusa Tenggara Timur, 30 November 1998 berkaitan dengan acara Perkabungan Massal untuk mengungkapkan rasa keprihatinan peristiwa Ketapang di Jl. Ketapang Petojo Jakarta Pusat 21 November 1998. Acara perkabungan massal yang diselenggarakan oleh pemuda-pemuda gereja yang tergabung dalam GAMKI, GMKI, PMKRI, Pemuda Katolik dan mahasiswa Kupang beserta pemuda-

\footnotetext{
"Mark Juergensmeyer, 2000, Terror in The Mind of God, AS: University of California, hal. 122-144.
} 
pemuda muslim dari unsur HMI berubah menjadi kekerasan yang sangat mengerikan karena terjadi pembakaran, perusakan dan pelemparan rumahrumah ibadah, seperti gereja, masjid dan fasilitas umum (sekolah dan pom bensin serta kantor pemerintah). ${ }^{4}$

Contoh lain yang sama-sama mengerikan adalah yang terjadi di Mataram, Nusa Tenggara Barat, dimana terjadi perusakan dan pembakaran gereja, serta numah-rumah orang Kristen di sana. Kerusuhan Mataram bermula dari kondisi pra kerusuhan dengan adanya provokasi yang mengancam kelompok Kristen dengan selebaran, kemudian penyelenggaraan tabligh akbar yang diselenggarakan di lapangan Pejanggik, kota Mataram dengan maksud mengungkapkan kerpihatinan terhadap saudara-saudara muslim di Ambon yang dilanda kerusuhan terus-menerus. Dalam pidato yang dilakukan oleh para tuan guru haji, ustadz dan alim ulama sekabupaten Lombok dinyatakan tidak ada perkataan yang menjelek-jelekkan apalagi menghujat kaum Kristen, tetapi setelah tabligh akbar selesai pukul 11.00, tepat pukul 11.00 selesai tabligh akbar sampai pukul 13.10 WITA pembakaran dan perusakan gereja serta rumah orang Kristen terjadi di kota Mataram, tanpa dapat dikendalikan oleh pihak aparat keamanan. ${ }^{5}$

Apabila dilihat dari niatan awalnya mungkin bisa dikatakan tidak ada maksud membuat kerusuhan, tetapi apa yang bisa kita lihat adalah bahwa fakta mengatakan orang-orang yang beridentitas agama tertentu ternyata membuat kerusuhan yang sangat berbahaya atas kelompok agama yang berbeda. Tentu kerusuhan tidak terjadi karena adanya penyebab tunggal, tetapi pelbagai penyebab menjadikan kerusuhan menjadi demikian besar dan memakan korban. Salah satu penyebab itu adalah dari agama yang memberhala, bukan humanis. Yang menarik dari kerusuhan-kerusuhan yang berada di belakang agama, senantiasa terdapat orang atau kelompok provokator. Terutama kerusuhan Mataram, terdapat beberapa nama yang disebut sebagai provokator seperti Zainal Asikin sebagai koordinator Tabligh Akbar, Sudiarto, sebagai koordinator perlengkapan tabligh akbar, Kaharuddin panitia, L. Winengan sebagai panitia, Amriful Hakim DPW PPMI, Eggy Sudjana, ketua pusat Perhimpunan Pekerja Muslim Indonesia, Anton Medan, Taufik Hidayat, AlChaidar, dan Ishak Sazaki. ${ }^{6}$

Apa yang bisa dibaca dari tuduhan adanya provokator yang semuanya berlatar belakang agama itu? Kalau bukan adanya kecurigaan atas kelompok

\footnotetext{
${ }^{4}$ Riza Sihbudi dan Moch. Norhasim (ed), 2001, Kerusuhan Sosial di Indonesia, Studi Kasus Kupang, Mataram NTB dan Sambas Kalbar, Jakarta: Grasindo, hal. 42-100. Akibat kerusuhan Kupang tersebut tercatat jumlah korban 16 orang meninggal, 81 luka-luka, 427 rawat jalan, 16 gereja dibakar dan dirusak, 1 masjid dirusak, 3 sekolah dibakar, 1 kantor koramil dirusak, 15 bank dirusak, 7 rumah dirusak, 32 mobil dibakar dan dirusak, 3 sepeda motor dirusak dan 6 kantor pemerintah dirusak serta 1 pom dirusak

'Lihat ibid., hal. 101-148

${ }^{6}$ Ibid., hal. 147-148
} 
agama yang "berbeda" dengan keagamaan yang dianut, maka apa lagi. Di situlah sebenarnya problem keagamaan kita benar-benar terjadi karena antara sesama umat beragama masih menyimpan rasa curiga, dan bahkan mungkin membenci, sehingga sangat sulit untuk menumbuhkan saling percaya dan dialog. Dialog dan kerjasama hanya akan berhenti dalam ucapan, tidak pernah terjadi dalam tindakan riil di tengah masyarakat yang memang membutuhkan uluran tangan agama-agama, apapun agamanya. Bahkan, sikap curiga dan membenci tersebut pada akhirnya memunculkan kekerasan suci.

Kekerasan agama atau sacred violence sebetulnya selain muncul dari adanya teks-teks suci, dogma, dan tafsir agama, juga disebabkan karena agama dijadikan sebagai barang yang magis dan serba mutlak. Agama dipandang tidak bisa diinterpretasikan, apalagi disesuaikan dengan keinginan manusia. Agama dipahami sebagai sesuatu yang serba teosentris, bukan antroposentris. Agama akhirnya menjadi "berhala-berhala baru", karena orang beragama menjadikannya idolatry bukan menjadikan agama sebagai kritik sosial. Dengan menjadikan agama sebagai berhala-berhala baru, orang beragama merasa dalam beragamanya paling sempurna, paling mutlak, sehingga orang lain pasti salah dan harus dipertobatkan. Disiniilah sebenarnya kekerasan dari agama benarbenar menemukan bentuknya yang paling sempurna.

Keagamaan yang demikian juga menempatkan manusia senantiasa berseberangan dengan Tuhan. Tuhan pada satu pihak, sementara manusia di pihak yang lain. Keagamaan pada akhirnya bertentangan dengan kemanusiaan sebagai bagian terpenting dari ajaran agama-agama. Agama bahkan berubah menjadi sesuatu yang serba ekstrim kemanusiaan. Kemanusiaan diperhadapkan dengan kodrat ketuhanan yang serba mutlak dan benar. Kebenaran mutlak Tuhan menutup kemuliaan untuk menghargai dan menghormati sesama umat manusia. Apa yang terjadi dalam masa-masa konflik di pelbagai daerah di nusantara akan semakin jelas mengindikasikan adanya pertentangan antara kemutlakan Tuhan dengan kemuliaan kemanusiaan.

Untuk menghilangkan keagamaan yang terkesan sangat sadis, cenderung berperang, anti kemanusiaan, tidak ada lain kecuali agama harus dirumuskan kembali sesuai dengan sifat-sifat kesalehan yang otentik berdasarkan keagamaan para Nabi dan rasul. Kisah-kisah konflik kekerasan pada zaman Nabi dan rasul harus ditafsir menjadi sebuah visi yang tetap memiliki universalitas tentang kedamaian, keselamatan, kesejahteraan bagi semua, semua umat beragama, muslim dan kafir. Hanya dengan keberanian melakukan dekonstruksi atas pemahaman agama yang konvensional itulah, agaknya kekerasan yang bersumber dari pemahaman agama perlahan-lahan akan mengalami penyusutan. Tetapi selama umat beragama enggan melakukan dekonstruksi atas pemahaman keagamaan yang selama ini- telah diyakini sebagai mutlak benarnya, maka dimensi kekerasan dalam agama akan tetap dominan. 


\section{Problem Dialog Antar Agama}

Sebagai negara pluralistik, Indonesia tidak saja ditempati oleh satu agama saja. Heterogenitas agama sangat jelas, riil adanya di sini, dan tidak bisa ditolak kehadirannya. Berkaitan dengan itu, pertemuan-pertemuan maupun ketegangan di antara para pemeluk agama juga tidak bisa dihindari. Bahkan bisa dikatakan bahwa sejarah agama-agama di Indonesia senantiasa diwarnai dengan pertemuan dan ketegangan itu sendiri, sehingga tak jarang menimbulkan salah persepsi, di antara para pemeluk agama itu sendiri.

Kondisi "saling mengintip" bahkan menjadi fenomena yang cukup kuat, yang tentu tidak kondusif bagi sebuah hubungan antar agama, karena yang terjadi kemudian adalah prasangka-prasangka yang salah, stereotipe, dan manipulasi di antara mereka. Sebagai salah satu upaya mengelimir adanya situasi kotor ini, dilakukanlah inisiatif untuk menggelar forum yang diikuti oleh banyak agama, dimana dari sana diharapkan akan terjadi banyak pertemuan, bukan melanggengkan ketegangan-ketegangan sebagaimana selama rezim Orde Baru senantiasa dilestarikan.

Dialog antar agama akhirnya menjadi salah satu cara yang ditempuh untuk "membuka mata" umat agama-agama agar tidak berpandangan picik, tertutup dan monolit. Banyak forum antar agama digelar, sejak dari tingkat RT/RW, kelurahan, desa, kecamatan, kabupaten bahkan propinsi dimana yang diikutkan di sana juga bermacam-macam kelompok dan golongan; sejak dari rakyat biasa sampai para pejabat birokrasi. Dialog bisa saja berjalan alot, namun tak jarang berjalan amat mudah sehingga mendapatkan butir-butir pemikiran yang sangat perlu diperhatikan untuk ditindaklanjuti dikemudian hari secara bersama. Pendek kata, dialog antar agama bisa berjalan sebagaimana rencana awal, untuk mempertemukan banyak kelompok agama sehingga sama-sama memiliki concern terhadap masalah bersama.

Sementara itu, dialog antar agama kadang berbuah pada semakin kuatnya rasa permusuhan dan kecurigaan di antara mereka: Hal ini tentu banyak penyebab yang melatarbelakanginya. Tidak ada satu penyebab tunggal terhadap gagalnya dialog antar agama, sehingga para aktivis antar iman dengan gampang membidik satu persoalan untuk kemudian diselesaikan secara bersama-sama. Bagian dari tulisan singkat ini hendak memberikan beberapa catatan penting berkaitan dengan isu dialog antar agama, sehingga dialog sangat sulit dialukan.

Sebagai sebuah upaya yang bisa dikatakan "melawan kebiasaan" masyarakat, dialog antar agama memang masih menyisakan banyak problem serius yang sering dihadapi oleh mereka aktivis penganut teologi dialogis, inklusif dan pluralis. Masyarakat "awam" yang telah terbiasa dengan satu cara pandang, titik tolak berpikir dan sikap dalam beragama tiba-tiba harus diperhadapkan dengan cara baru, sehingga tak jarang menolaknya dengan pelbagai alasan. Banyak hal yang menjadi alasan mengapa orang sulit melakukan dialog antar agama. 
Pertama, identitas kelompok. Banyak dari masyarakat kita jika harus melakukan dialog antar agama akan merasa kehilangan identitas kelompoknya, atau paling sedikit merasa bagaimana bisa mempertahankan identitasnya, sehingga orang lain memahami bahwa antara kelompoknya dengan yang lain memang benar-benar berbeda. Perasaan akan hilangnya identitas, bila kita lacak lebih jauh sebenamya berkaitan dengan prejudice antar kelompok, sehingga menimbulkan adanya penguatan adanya "kami-mereka" atau we and the others. Bahkan yang paling jelas dari adanya rasa hilangnya identitas kelompok adalah adanya ketidakpercayaan terhadap pihak lain, atau lawan yang diajak dialog. Bassam Tibi menyatakan bahwa identitas kelompok ini merupakan sumber konflik antar agama karena di sana mengandaikan adanya persaingan identitas-

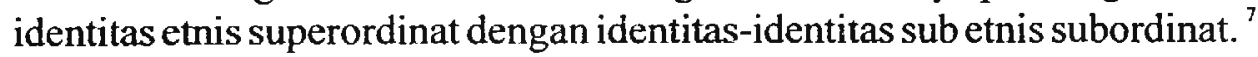

Dengan kondisi semacam itu, maka dialog antar agama yang digagas dan digelar bersama seakan-akan tidak berarti. Sekalipun sebenarnya arti dari dialog itu sendiri adalah paling tidak kita telah mendapatkan bekal bahwa di dalam masyarakat memang ada yang berbeda dengan kita, tidak semua sama dan karena itu tidak bisa dipersatukan. Program unifikasi sebagaimana pernah dilakukan oleh rezim otoriter telah terbukti memperburuk hubungan antar agama di tanah air, sekalipun dikampanyekan sebagai negeri yang hidup harmonis antara satu pemeluk agama dengan pemeluk agama yang lain.

Kedua, konsepsi dan persepsi. Konsepsi dan persepsi awal yang salah terhadap kelompok lain adalah halangan yang serius dalam dialog antar agama. Berangkat dari persepsi dan konsepsi yang salah, kurang paham dan ngawur maka yang akan terjadi kemudian adalah berkembangnya misunderstanding yang lain. Bukan hanya ini, tetapi antar peserta dialog antar agama biasanya juga, saling membangun opini publik yang salah. Hal ini sangat disayangkan karena semakin terbangun opini publik terhadap pihak lain dengan persepsinya yang salah tersebut, maka semakin banyaklah orang-orang yang "terperanga" dalam ketidaktahuan dan ketidakjelasan konsepsional dan persepsional tentang agama orang lain. Akibat lanjutannya adalah kesalahan berantai ibarat spiral yang bergulung-gulung tingkat kesalahannya. Dari spiral kesalahan ini pula yang menyebabkan terjadi spiral kekerasan atas nama agama.

Dialog antar agama yang berangkat dari ketidakjelasan konsep dan persepsi yang kacau pada akhirnya hanya akan membuahkan forum yang saling menghujat, mengadili dan membenarkan kelompoknya. Dialog tidak akan pernah terjadi ketika tataran konsepsional dan persepsional tentang kepelbagaian agama tidak diselesaikan terlebih dahulu. Yang terjadi pada tataran ini hanyalah serial monolog, sebagaimana pernah dilakukan oleh proyek

\footnotetext{
${ }^{7}$ Lihat Bassam Tibi, "The Challenge of Fundamentalism Political Islam and the New World Order", dalam Imron Rosyadi dkk (terj.), 2001, Ancaman Fundamentalisme Rajutan Islam Politik dan Kekacauan Dunia Baru, Yogyakarta: Tiara Wacana, hal. 224.
} 
negara melalui Departemen Agama RI pada tahun-tahun 1980-an hingga tahun 1990-an.

Ketiga, ideologisasi agama. Kesulitan ini dalam dialog antar agame merupakan kesulitan yang sangat fundamental karena pengalaman sejarah masa lalu, sepanjang Orde Baru, agama memang diajarkan untuk menjadi ideologi, bukan bagaimana agama menjadi agen transformasi sosial (agent of social change). Kenyataan agama hanya menjadi ideologi sangat jelas ketika agamaagama di negeri ini, tak lebih jadi "kuda troya" politik kekuasaan. Proyeksi negara atas agama demikian kental ketika pesta lima tahunan yang kita kenal dengan Pemilu digelar. Bagaimana banyak ulama-ulama, kiai dan tokoh masyarakat dari kalangan Islam beramai-ramai untuk mensukseskan Pemilu, bahkan mendukung partai politik milik pemerintah (baca: Golkar), dengan janji-janji apabila Golkar menang maka desanya akan mendapatkan fasilitas yang lebih baik, seperti pengaspalan jalan, listrik masuk desa dan pembanguan fasilitas lain yang bersifat mercusuar simbolik.

Bahkan yang paling kentara dengan adanya proyek ideologisasi agama yang terjadi adalah lembaga-lembaga turut serta dalam permainan politik rezim, sehingga lembaga-lembaga agama seperti MUI (Majelis Ulama Indonesia), PGI (Persekutuan Gereja Indonesia), Parisadha Indonesia, Walubi (Wali Umat Budha Indonesia), dan KWI (Konfrensi Wali Gereja Indonesia) tidak lebih sebagai pembenar proyek-proyek negara, seperti melancarkan proyek pembangunan jembatan raksasa, proyek pembangunan bendungan, proyek transmigrasi dan proyek keluarga berencana.

Seiring dengan hal itu, proyek ideologisasi agama oleh negara telah pula menciptakan simbol-simbol ektrim dan ekslusif dalam keberagamaan. Idiomidiom fundamentalis, eksrim kanan, ekstrim kiri merupakan idiom paling lazim digunakan rezim penguasaan dan tentara. Memang belakangan, sejak terbentuknya ICMI, kekuasaan Orde Baru di bawah Soeharto agak berkurang dalam melakukan tuduhan-tuduhan kasar terhadap Islam, tetapi tidak berarti Islam tidak dimanfaatkan oleh kekuasaan Soeharto untuk mendukung keberlangsungan kekuasaannya. Sifat akomodatif rezim Orde Baru terhadap Islam sangat jelas diperlihatkan ketika dukungan militer terhadap Soeharto mulai berkurang, sementara Islam dianggap sebagai potensi besar untuk dijadikan kawan bermain. ${ }^{8}$

Dengan kenyataan semacam itu, agama pada akhirnya sangat sarat dengan politik, tepatnya politisasi agama oleh para birokrat negeri ini. Agama hanya akan berfungsi ketika di belakangnya ada implikasi politik yang ditawarkan,

\footnotetext{
${ }^{8}$ Catatan tentang ini bisa dilihat dalam karangan Bahtiar Effendy, 2001, Islam dàn Negara, Jakarta: Paramadina, hal. 242-248. Bassam Tibi menyebut masa ideologisasi agama dalam kasus Islam sebagai era repolitisasi Islam (Islamic politization) yang dianggap sebagai alternatif dari tatanan dunia baru sekuler oleh kaum fundamentalis yang bersifat milerianistis.
} 
tanpa akibat politik yang jelas di belakangnya, jangan berharap agama-agama akan dilirik. Akibat lanjutan dari kondisi semacam ini adalah terjadinya mental eksklusivisme dalam beragama, sehingga untuk dapat menerima kehadiran orang-orang yang berbeda pandangan; dan cara ritual keagamaan sangatlah alergi. Eksklusivisme menjadi fenomena yang sangat populer di masyarakat beragama.

Eksklusivisme agama sebenarnya bisa dikatakan sebagai akibat dari munculnya para pemimpin agama yang "negatif", yaitu pemimpin agama yang tidak bisa menjadi pengayom dan pembimbing umatnya, namun memprovokasi umatnya untuk bertindak sesuai dengan kepentingan dan target-target politiknya. Oleh sebab itulah, di sini dibutuhkan kehadiran pemimpin agama yang "positif", dalam arti mampu memberikan pencerahan bagi umatnya, sehingga bermanfaat bagi seluruh manusia.

Keempat, isu mayoritas-minoritas. Isu ini akan menguat dalam dialog antar agama disebabkan karena berkaitan dengan tuntutan equality yang masih dipertanyakan oleh pihak-pihak yang berdialog. Menguatnya isu mayoritasminoritas akan terjadi ketika dalam sebuah masyarakat yang beragama agama terjadi perlakukan diskriminatif, sehingga menimbulkan kecemburuan sosial di antara warga masyarakat yang berbeda-beda agama tersebut. Dari perlakuan diskriminatif tersebut, akhirnya penganut agama yang merasa diperlakukan tidak adil akan menuntut keadilan. Isu pun berkembang pada wilayah bahwa "kita mayoritas "atau "kita minoritas" yang sangat tidak kondusif untuk sebuah pertemuan dialog antar agama. Dengan dua kategori semacam itu, yang terjadi adalah pertarungan siapa yang berhak dan yang tidak berhak, terutama dalam persoalan persentase jumah pengikut. Yang merasa mayoritas tentu akan bertahan pada pendiriannya bahwa mereka inilah yang paling berhak, sementara yang minoritas harus mengalah.

Persoalan mayoritas dan minoritas ini pernah diungkap dalam laporan sebuah majalah ibukota, dimana dalam majalah tersebut dilaporkan bahwa Pemilu tahun 1992 merupakan era kebangkitan umat Islam, karena Islam sebagai agama mayoritas. "DPR Ijo Royo-Royo, Kini Giliran Kita", tulis media tersebut, mengutip salah seorang tokoh Islam yang aktif dalam NGO (Non Govemmental Organization) dan sekarang menjabat sebagai Ketua ICMI, sebuah media terkenal yang kemudian dibredel awal tahun 1993, bersama Detik dan Editor. Memang kasus pembredelan ketiga majalah ibukota ini bukan berkaitan berita tentang DPR, tetapi masalah lain.

Kelima, konvèrsi agama. Konversi agama atau perpindahan agama akan menjadi isu yang paling krusial ketika sebuah dialog antar agama digelar. Para penganut agama yang ikut dalam dialog seringkali mempertaruhkan namanya dengan mengatakan bahwa dari jamaahnya banyak yang berpindah ke agama lain karena pengaruh agama lain, bukan agamanya. Perpindahan agama (konversi agama) seringkali berkaitan dengan apa yang kita sebut misi atau 
dakwah dalam agama-agama. Aktivitas misi atau dakwah yang sebenarny bukanlah kegiatan "haram" akhirnya bahkan menjadi kambing hitam dalan dialog antar agama.

Pertanyaannya, dakwah atau misi yang bagaimana sehingga menjad kambing hitam dalam dialog antar agama, ini merupakan persoalan serius yan harus dijawab oleh para penyebar agama-agama, sehingga sekalipun ad perpindahan agama merupakan perpindahan yang dianggap wajar dan rasiona. Namun, untuk menuju pada pemahaman bahwa perpindahan agama (konversi merupakan hal yang wajar tampaknya memang masih butuh waktu yan. panjang sehingga tidak menjadi alasan untuk mengganyang pihak lain dalar. dialog antar agama.

Penulis sendiri tidak setuju apabila dakwah atau misi hanya ditafsirka sebagai kegiatan mengislamkan atau mengkristenkan orang yang suda beragama. Kegiatan "mengagamakan" orang yang sudah beragama, penuli anggap sebagai aktivitas dakwah atau misi yang tidak beradab. Sebuah aktivita yang bertentangan dengan harkat dan martabat kemanusiaan. Oleh sebab itulak misi atau dakwah yang harus dikembangkan haruslah misi atau dakwah yan lebih bercorak emarsipatoris-transformatif. Sebuah misi atau dakwah yan. membahas masalah-masalah umat manusia secara keseluruhan, sepen ketidakadilan, kemiskinan, kebodohan, HIV/AIDS, orang jompo dan anak anak terlaniar.

Apabila misi atau dakwah diarahkan pada masalah-masalah riil $d$ masyarakat penulis kira aktivitas misi atau dakwah akan mendapat simpal umat, sehingga didukung. Tetapi apabila dibalik misi atau dakwah terdapa agenda-agenda tersembunyi yang ingin dicapai, mengkristenkan ata mengislamkan orang, penulis kira ini menjadi problem serius dialog anta agama, karena akan senantiasa berkaitan erat dengan perpindahan agama.

Dalam Islam memang kegiatan dakwah amr ma'rǘf nahy munkar menempal bagian tersendiri, sehingga setiap umat Islam diwajibkan untuk berdakwar Persoalannya adalah bagaimana metode, model, apa dan siapa yang menjad objek dakwah sangat jarang dibahas secara detil. Umat Islam sering lupa, bahw. dakwah harus dilakukan dengan cara yang ma'rüf, bijaksana dan lebih ke dalan (dalam diri sendiri dan keluarga), bukan melakukan invansi kepada yang lai sementara diri sendiri dan keluarganya diabaikan.

Hal yang sama juga terjadi dalam lingkungan Kristen. Misi terlalu serin: dipahami sebagai proses "mengkristenkan" orang lain, sehingga tercapailal kerajaan Allah di muka bumi. Kekristenan dan kerajaan Allah ditafsirkan ketik semua orang beragama Kristen, maka secara otomatis menjadi pengikut Yesu yang setia, dan memuliakan kerajaan Allah.

\section{E. Penutup}

Sebelum penulis mengakhiri tulisan ini, perlu penulis katakan kembal bahwa isu-isu yang tertulis di atas tidaklah menutup kemungkinan isu lain 
Mungkin masih terlalu banyak isu yang seringkali muncul dalam dialog antar agama, sehingga dialog antar agama mandeg sama sekali. Namun, bisa juga isu di atas untuk kasus-kasus tertentu tidak muncul. Yang paling penting buat penulis adalah bagaimana dialog antar agama berjalan dengan baik dan membuahkan agenda-agenda konkrit yang bisa dikerjakan bersama-sama, tanpa harus meniadakan peran orang lain di sana. Salah satu bukti orang beriman adalah mampu bekerja sama dengan orang lain dalam menangani masalah-masalah kemanusiaan yang muncul.

Sebagai catatan penutup, sekarang ini perlu sebuah konsensus bersama yang benar-benar mengikat antara elit politik dan agama dengan masyarakat yang dibuat dan ditaati bersama untuk mengatasi kekacauan dan krisis yang lebih besar. Rekonsiliasi nasional antar elit dan antar generasi perlu segera dilakukan segera, bukan tetap pada tradisi menang-menangan, atas nama agama sekalipun. Tidak ada perdamaian dunia tanpa perdamaian agama. Tak ada perdamaian agama tanpa perdamaian dunia. Kita adalah hidup dalam realitas pluralitas yang merupakan sunatullah, sekaligus harus menjadi way of life, dari sinilah demokrasi dalam kehidupan beragama akan tumbuh. Salah satu lembaga keagamaan yang penulis anggap paling penting dalam proses perdamaian (rekonsiliasi) adalah $\mathrm{NU}$ dan Muhammadiyah, serta NGO-NGO yang secara khusus bergerak datam isu keagamaan, tanpa bermaksud mengabaikan NGO lainnya.

\section{DAFTAR PUSTAKA}

Appleby, R. Scott, 2000, The Ambivalence of the Sacred, Religion, Violence, and Reconciliation, AS: United State of America.

Budiwanti, Erni, 2001, Islam Sasak, Yogyakarta, LKiS.

Effendy, Bahtiar, 2001, Islam dan Negara, Jakarta: Paramadina.

Johnson, James Turner, "The Holy War Idea in Western and Islamic Tradition", dalam Ali Noor Zaman (terj.), 2002, Ide Perang Suci dalam Tradisi Islam dan Barat, Yogyakarta: Qalam.

Juergensmeyer, Mark, 2000, Terror in The Mind of God, AS: University of California.

Sihbudi, Riza, dan Moch. Norhasim (ed), 2001, Kerusuhan Sosial di Indonesia, Studi Kasus Kupang, Mataram NTB dan Sambas Kalbar, Jakarta: Grasindo.

Tibi, Bassam, "The Challenge of Fundamentalism Political Islam and the New World Order", dalam Imron Rosyadi dkk. (terj.), 2001, Ancaman Fundamentalisme Rajutan Islam Politik dan Kekacauan Dunia Baru, Yogyakarta: Tiara Wacana. 